\title{
The emergence of God's new people: The beginnings of Christianity reconsidered
}

\author{
Wolfgang Stegemann (Augustana Hochschule, Germany) ${ }^{1}$ \\ Research Associate: Department of New Testament Studies \\ University of Pretoria
}

\begin{abstract}
The article deals with the problem of the Christian beginnings. Unlike many other scholars, the article does not defend the traditional metaphor which compares Judaism and Christianity to the relationship of mother and daughter. It also does not take for granted that ancient Judaism and Christianity can be viewed as religious. The category "religion" is a modern concept and therefore does not meet the ancient discourse. The article aims to argue that the emergence of Christianity could be better understood in terms of "ethnicity". Another version of the article was published in Di storia dell' esegesi 21(2), 2004, 497-513.
\end{abstract}

Jede Vorstellung von Anfängen verleitet dazu eine Fabel zu konstruieren (Jean Starobinski)

\section{INTRODUCTION}

We are witnessing today an extraordinary resurgence of interest in the beginnings of Christianity. The most recent scientific discourse is all the more remarkable for being carried out on both an international and interdisciplinary level. Since the beginnings of Christianity are directly interwoven with the situation of Judaism of the time, our research profits from this circumstance in so far as the current enquiry engages the participation not only of representatives of historiography and the historical disciplines of Christian

\footnotetext{
${ }^{1}$ Prof Dr Wolfgang Stegemann is Rector and Professor of New Testament at the Augustana Hoschschule, Neuendettelsau, Germany. Prof Stegemann is a research associate of Prof Dr Andries G van Aarde, Professor Emeritus, Department of New Testament Studies, Faculty of Theology, University of Pretoria.
} 
theology (such as New Testament exegesis and church history) as well as sociology, but also experts on ancient Judaism. ${ }^{2}$

I assume that the emerging priority of this topic in related sciences is no mere matter of chance. Therefore, it is worthwhile reflecting on the inner scientific, but also social and cultural factors that have determined such a profound interest in the subject under consideration. This question, in turn, leads us towards a different discourse: a discourse about a discourse, in a certain sense. And this topic, in turn, is primarily rooted in the sociology of knowledge, given the order of scientific disciplines which has prevailed in modern times. I mention this aspect, because my objective is to contribute to the discussion on the beginnings of Christianity in two ways. On the one hand, I wish to present a hypothesis concerning the emergence of Christianity within the Mediterranean cultures; on the other, I want to question and debate some of the assumptions of the prevailing discourse. I therefore intend to concentrate on two basic problems of the discourse about the discourse, while going on to provide a brief outline of my own ideas about the beginnings of Christianity.

\section{TWO PROBLEMS OF THE PRESENT DISCOURSE ABOUT THE BEGINNINGS OF CHRISTIANITY}

\subsection{Deconstructing genealogical metaphors}

As far as I can see, the numerous analyses on the beginnings of Christianity agree in principle that we are dealing with an investigation into the formation (or the origins) of a (new) religion. The aim of this scientific endeavour is to find answers to questions such as: when, in which contexts, and under which circumstances did the Christian religion start its development? I would like to show that this approach to the subject in question, to deal with ancient Christianity as if it where a religion, is an anachronistic concept. I will explain my reservations about this interpretation of the present subject below. I start instead with a kind of deconstruction of some of the kinship metaphors, which not only dominate but characterise the discourse.

In addition to the terms emergence or origins of early Christianity, we also prefer to use the organic metaphor of birth, to describe the beginnings of Christianity. I openly admit that only a year ago I asked my publisher (Kohlhammer Verlag) to secure the copyright for a special book title (you have

\footnotetext{
${ }^{2}$ See, for example, Boyarin (1999); Castelli (1998:227-257); Frend (1984); Lüdemann (2000); Mack (1995); Sachot (1998); Stegemann \& Stegemann (1999); Stegemann (2001); Theissen (2000); Strak (1996); Collins (1993); Crossan (1999); Trevijano (1994); Simonetti (1994); Jossa (1997); Mimouni (1998); Destro (2000); Nodet \& Taylor (1998); Segal (1986).
} 
to apply for it at the Boersenverein des Deutschen Buchhandels): Die Geburt des Christentums, that is The birth of Christianity. In the meantime, however, I have changed my mind, and unfortunately so, for the title is obviously very appealing. Let me explain this change of heart.

As a consequence of the basic metaphor of birth scholars deduce new metaphors to name their specific view of the birth of Christianity. Thus, some of them - like my German colleague Gerd Theissen $(2000)^{3}$ - take Christianity as the daughter of Judaism, which is in their view its mother religion. Others, however, are of the opinion, that Christianity and Judaism emerged at about the same time and under similar social and cultural conditions. Therefore they use the metaphor of a twin birth. Alan F Segal (1986) even has a special pair of twins in mind, that is Rebecca's children. By using the twin birth metaphor Segal presupposes that Judaism and Christianity came into being at the same time, and he explicitly is not convinced - along with Theissen and many other scholars - that one of them, that is Judaism, gave birth to the other, that is Christianity. Segal (1986:1-2) writes:

\begin{abstract}
Judaism and Christianity can essentially claim a twin birth. It is a startling truth that the religions we know today as Judaism and Christianity were born at the same time and nurtured in the same environment ... When Jesus was born, the Jewish religion was beginning a new transformation, the rabbinic movement, which would permit the Jewish people to survive the next two millennia. The complex of historical and social forces that moulded rabbinic Judaism also affected the teaching of Jesus, helping to form Christianity into a new and separate religion.
\end{abstract}

It should be noted that the use of different metaphors - although both of them derive from the basic metaphor "birth" of Christianity - include very distinct conceptions. The use of tropes in historiography does not only serve the mere illustration of ideas or expressions. Paul de Man somewhere affirmed: "tropes are not just travellers, they tend to be smugglers and probably smugglers of stolen goods at that." And no one more than Hayden White has so directly pointed out the fundamental problem of the use of tropes in historiography. Even Klio, the Muse, is a poet (White 1985). Unfortunately I cannot enter into the recent debate on the theory of history, but I am willing to concede that we probably cannot do without metaphors in historiography. However, it must be taken into consideration that the scientific discourse is laid down and structured by metaphors. It is worth dwelling briefly on this point.

\footnotetext{
${ }^{3}$ See my review "Christentum als universalisiertes Judentum? Anfragen an Theissens "Theorie des Urchristentums" (Stegemann 2001:130-148).
} 
Firstly, genealogical metaphors - like that of mother and daughter - are problematic, because they imply an organic relationship between the historical phenomena they refer to. In the present case, if we understand the relationship between Judaism and Christianity as the relationship of mother and daughter, we are bound to understand the emergence of Christianity as an organic process, in analogy to a birth, be it a complicated or an easy one. In contrast to this view, the only metaphor to be found in the New Testament which is comparable in the context, does not suggest an organic connection between Judaism and the newly formed "Christian" groups, but a break and a manifest discontinuity. I am referring here to Paul's olive tree image, which he uses in Romans 11:17-20 in order to make clear his opinion about the relationship between so called Gentile "Christians" and Judaism or Israel.

17 Now if some of the branches have been cut off, and you, a wild olive branch, have been grafted in among them and become partakers of the rich root of the olive tree,

18 do not boast over the branches. But if you are to boast, remember that it is not you who supports the root, but the root that supports you.

19 You will say then, "Branches have been broken off in order that I might be grafted in,"

20 True. They were broken off because of lack of faith, and you stand because of faith. Do not think highly of yourselves, but fear. ${ }^{4}$

The text speaks about "branches" of the olive tree, which "have been cut off", and other branches of a wild olive tree, which "have been grafted in among them and became partakers of the rich root of the olive tree" ( $v$ 17). The thrust of the metaphor is to argue against any boasting of so-called "Gentile Christians" over Jews. What is interesting in the context here is that the metaphor implies a kind of artificial, hortatory scope. Further on it implies a break, a discontinuity or disjunction between Israel, represented in the noble olive tree, and the Gentile Christians, who joined God's people through their belonging to Christ.

Secondly, the mother-daughter metaphor almost inevitably goes with an evolutionary model of progress. Following this model we will automatically think of Christianity as the new born religion in terms of progress and development. Breaks, discontinuity, a step backwards, are not contemplated in any way. The genealogical metaphors are basically in agreement with the traditional model of historical progress and continuity, which is mostly understood as a development in terms of achieving higher levels. Under such

\footnotetext{
${ }^{4}$ English translation follows D Moo (1996:696-697).
} 
conditions a judgement of qualitative preference between mother and daughter, Judaism and Christianity, is not easy to avoid. As a rule, you will find anti-Jewish judgements in the publications representing the older discourse on the beginnings of Christianity. I only mention two examples here: Adolf von Harnack and Wilhelm Bousset. Both of them understood Judaism as the mother religion of early Christianity, which in their opinion achieved a higher level than the mother because of its universal perspective. The universality of Christianity has overcome - as they see it - the nationalistic or ethnocentric and particular character of the mother. Very well known is the following statement of Harnack:

Eine solche Ungerechtigkeit wie die der Heidenkirche gegenüber dem Judentum ist in der Geschichte fast unerhört. Die Heidenkirche streitet inm alles ab, nimmt inm sein heiliges Buch, und, während sie selbst nichts anderes ist als transformiertes Judentum, durchschneidet sie jeden Zusammenhang mit demselben: die Tochter verstößt die Mutter, nachdem sie sie ausgeplündert hat!

A reading of these sentences in isolation suggests that Harnack complains about the (Christian) daughter's exploitation of the Jewish (mother) religion. However, in order to understand his complete argument, one must read a little further:

\begin{abstract}
Aber ist diese Betrachtung wirklich zutreffend? Auf einer gewissen Stufe allerdings, und vielleicht kann man niemanden zwingen, sie zu verlassen. Aber auf einer höheren Stufe stellt sich die Sache anders dar: das jüdische Volk hat durch die Verwerfung Jesu seinen Beruf verleugnet und sich selbst den Todesstoß versetzt; an seine Stelle rückt das neue Volk der Christen; es übernimmt die gesamte Überlieferung des Judentums; was unbrauchbar in derselben ist, wird umgedeutet oder fallen gelassen. In Wahrheit ist diese Abrechnung nicht einmal eine plötzliche oder unerwartete; unerwartet ist nur die spezielle Form: Das Heidenchristentum führt doch nur einen Prozeß zu Ende, der in einem Teile des Judentums bereits längst begonnen hatte - die Entschränkung der jüdischen Religion und ihre Transformation zur Weltreligion.
\end{abstract}

(Von Harnack 1924:76)

I will not, at this point, go any deeper into a critical assessment of the antiJewish stereotypes which are used in this short text. For the moment, it is sufficient to concentrate on one point: When Harnack applied the motherdaughter model to the beginnings of Christianity, the metaphor implied a 
specific presupposition - the particularism of Judaism and the universalism of Christianity. Harnack understood the Christian religion as the end product of a process of universalizing Judaism, or, alternatively, as a kind of denationalizing Judaism. The same argument is advanced in the book Das Wesen der Religion by Wilhelm Bousset (1903:192), which was published a year after Harnack's book in question. But it is also encountered a hundred years later in the present discourse surrounding the beginnings of Christianity - admittedly without anti-Jewish stereotypes (Theissen 2000). ${ }^{5}$

Reflecting on the "modern consensus of race as incongruent with early Christian self-definition", Denise Kimber Buell (2001:449-476) in her enthusiastic article about the "the relevance of race for early Christian selfdefinition" states:

... defining Christianness in contrast to race has not solved the problems of modern racism and anti-Judaism. While important for antiracist interventions, this definition has not eradicated modern racism within Christianity, as churches remain primarily organized along racial and ethnic lines. This definition also sustains an antiJewish interpretive lens. If universalism is defined in contrast to racial specificity, and universalism is seen as a distinctive feature of Christianness, then Christianness is defined as not-race particularly over and against Jewishness as race. Even when the goals of this logic are valuable - to end racism, for example - this construction of universalism paradoxically perpetuates racist anti-Judaism in the name of antiracism.

Kinship metaphors produce hierarchies, inevitably so, if one speaks of Judaism as mother and Christianity as daughter. The concrete significance of the hierarchy depends on how one culturally or personally assesses the social differences between mother and daughter. In a similar vein the twin metaphor, especially in terms of the Biblical twins Jacob and Esau, Rebecca's children, raises the question: Which of the two religions is Jacob and which is Esau? In other words, which of them is at the top of the hierarchy or is the better son? Furthermore, if the twins represent the origins of what we call today Judaism and Christianity, what does Rebecca, their mother, represent? The answer is (if I understand Segal correctly) that Rebecca represents an earlier version of "Judaism", that is "Judaism" before (rabbinic) "Judaism". While not denying that many changes and discontinuities within "Judaism" arose in the first century, it seems to me, that by coining the metaphor "Rebecca's children" we

\footnotetext{
${ }^{5}$ See my critical review of Gerd Theissen's remarkable book, in the article in the journal Kirche und Israel (W Stegemann 2001:130-148).
} 
experience another kind of birth, the birth of a referential entity for the mother of the twins ("Rebecca").

Thirdly, I attempt to take my deconstruction of the kinship metaphors one step further. Daniel Boyarin criticised, with good reason I believe, all kinds of kinship metaphors. In his inspiring book Dying for God: Martyrdom and the making of Christianity and Judaism, Boyarin (1999:8) writes: "I suggest that the kinship metaphors need to be abandoned, for they imply, ipso facto, the kinds of organic entities and absolute separations that it is precisely the work of this text to displace ...."

As a matter of consequence, kinship metaphors urge us to think of Judaism and early Christianity as absolutely separate entities. This reminds me of J G Herder and his metaphor for the different cultures of the world. His idea was that all the different cultures of the world are like "spheres" or balls, existing side by side, but always separated from each other, without any chance of overlapping or influencing each other. This image or metaphor allows only for the idea of cultural homogeneity, of secluded or closed entities. Herder's sphere-model, which served his aim of understanding the new insight, that culture exists only in the plural, does not allow us to think of cultures as heterogeneous entities, that may have experienced interdependences, mutual influences, not to mention the favourite term which dominates the recent discourse of cultural theories, "hybridity", the mixture or melange of different cultures (see especially, Homi K Bhabha 1994).

Let me now apply these insights briefly to the discourse about the beginnings of Christianity. My conclusion is: All kinship metaphors be it the birth metaphor, the metaphor of mother and daughter or the twin-metaphor, presuppose an understanding of the beginnings of Judaism and Christianity, which assumes them to be separate, self-standing entities that are clearly definable against each other. However, this is the question.

The aforementioned Daniel Boyarin, who is professor for Talmudic culture at the University of Berkeley, has questioned this idea of neatly divided or separated religions of Judaism and Christianity, at the time of their emergence. And it is my opinion, too, that we have to contemplate parallel histories of Judaism and Christianity, histories however, which were interwoven which each other. Until the beginning of the $4^{\text {th }}$ century it was according to Boyarin - very difficult to draw clear borderlines between Christians and Jews. This fuzzy situation makes him speak of "JudaeoChristian Origins". Moreover, he believes, that the two religions have been "intertwined cultures", and that they "made" each other. Boyarin's (1999:8) analysis follows Homi K Bhabha and his theory of hybridity in Bhabha's (1994) book The location of culture. Briefly, by using a metaphor we try to surprise people and induce them to see something in a new way. This is true for the 
kinship metaphors that have been used within the context of the subject under consideration. However, "when a metaphor becomes conventional and established, and when it loses its novelty ... it begins to function strictly as a model and so becomes a 'lens' through which we view" the subject. ${ }^{6}$ It seems to me that we have recently been witnessing this function of metaphorical language applied to the beginnings of Christianity. The time-honoured, frequently employed kinship metaphors for the emergence of Christianity function like a "lens" or like glasses, which provide our historical analysis with a kind of fixed meaning system. Such organic metaphors not only illustrate, but design or shape, even coin the picture of the historical phenomenon under consideration. I turn now to a second observation of the problem in question.

\title{
2.2 Religion as an anchronistic conception
}

Most of the studies on the emergence of Christianity presuppose that the subject matter of their research is an ancient religion. The notion, whether defined or not, refers to a separate, definable entity, an independent area of human experience or culture. Just this point of view is implied within the above metaphors, as I have attempted to show in my first paragraph. However, the possibility of speaking of religion in this way has existed only since the 17th or 18th century. This is the conclusion of the fundamental study of W Cantwell Smith (1991), published in his book The meaning and end of religion, which has been acknowledged since then in various regards. To put it briefly, the discourse about religion in terms of "any system of doctrines and practices, any institutional phenomenon or historical development, one of the 'religions' of the world" (Smith 1991:34) is a relatively modern phenomenon, and was cultivated during the Enlightenment. Religion, in this sense, is a product of the Euro-American cultures of modernity, dominated by Christianity. Richard King (1999:210) is even of the opinion:

\begin{abstract}
"Religion" ... is a theoretical construction useful for the purposes of examining one particular aspect of the human experience but should not be reified, as if it could exist apart from that context. Increasing academic specialization, appeals to the sui generis and privileged status of religion, and the legitimation and preservation of the institutional "expert on religion" in the secular Academy, have all led to a tendency to treat "religion" as if it were more than an explanatory construct with a particular cultural and ideological genealogy of its own.
\end{abstract}

This Euro-American conception of religion, which was coined by Christianity, is - in popular discourses as well as in the special discourses of specialised

\footnotetext{
${ }^{6}$ Dieter Reinstorf 2002. Metaphorical stories in Luke's narrative world: A challenge to a conventional worldview. DD dissertation, University of Pretoria.
} 
sciences like the history of religions or theology - mostly connected with an essentialist theory. Scholars who prefer this approach take religion as a substance or essence which precedes the discourse of religion. In addition, they understand concrete religions like Islam or Judaism or Christianity as specific manifestations of the religious essence, specific insofar as they are a manifestation within a certain culture and time. In the course of the debate the religious essence was defined in various ways.

During the Enlightenment period the religious essence was located within the area of reason alone (Immanuel Kant), while Friedrich Schleiermacher and the Romantic period found the substance of religion in another human province, an area that we Germans call "Gemüt", more generally: in the area of sentiments and feelings. I would like to remind you of Romain Rolland, who in this context coined the expression "oseanic feeling" in a letter to Siegmund Freud. Rudolf Otto (1869-1937) ${ }^{7}$ whose conception of religion was very influential, remained within this Romantic idea of religion, and the famous scholar Walter Burkert ${ }^{8}$ recently attempted to transform Otto's religious categories (augustum, tremendum, fascinosum) into categories of biological anthropology.

From the German news magazine Der Spiegel, I learned that neurologists recently located human religious competence in the region of the temporal lobe. In this region, they say, our brain registers perceptions, including those illusions among which the neurologists obviously count religion. In my view, this biological confirmation is a late triumph of Freud's critique of religion. Many sociologists and cultural anthropologists look for religion in a totally different area of human experience. They locate religion within society or culture. To mention only one, it is worth remembering Clifford Geertz and his famous definition of religion as special meaning system. At the present time Dario Sabbatucci (1988:43-58) states that the history of research of religion tends to dissolve the concept of religion within that of culture.

What all the different localisations of religion have in common is that religion is understood within the framework of an essentialist theory, that is, as something "out there", an external entity, a kind of real thing beyond the discourse of religion. This point of view includes the existence of a religious essence or substance, which transcends history as well as culture, and it sees concrete religions like Islam or Judaism or Christianity as its historic and cultural manifestation. In contrast to this essentialist approach I would

\footnotetext{
${ }^{7}$ Rudolf Otto 1926. Das Heilige über das Irrationale in der Idee des Göttlichen und sein Verhältnis zum Rationalen. Gotha: Leopold Klotz.

${ }^{8}$ Walter Burkert 1988. Kulte des Altertums: Biologische Grundlagen der Religion. München: C H Beck.
} 
understand religion as a discourse, an idea that dates back to the Enlightenment and is now widely circulated especially within the EuroAmerican cultures. As a result, if we apply our perception of religion to other cultures, ancient or contemporary, we will necessarily understand or interpret them according to the model of Christianity, which in the discourse of religion serves as the prototype of religion. In other words, to understand early Judaism or early Christianity in terms of religion means to construct them as analogies to modern Christian religion, which is the model and the measure of what we call a religion.

My conclusion is as follows. The discourse of religion as we know it is a cultural construction of Euro-American societies, which emerged during the period of Enlightenment and formed a new system of knowledge. As one of the consequences of the emergence of this special discourse, the EuroAmerican cultures developed new academic disciplines for the study of this new system of knowledge, for example history of religions, to mention only one example. The new science of religion classified and shaped its subject, generally speaking by providing participants in the discourse of religion with a kind of order, designating its categories and deciding what belongs to the discourse and what has to remain outside of it. In this way, the discourse functions like a channel. Along with these important epistemological conclusions about the emergence of religion as a knowledge system, there is the accompanying insight that religion can be understood as a separate region of human experience. Since then, we have been able to speak of a special region of human experience, which William James [1902] [1985] 2003) at the beginning of the 20th century called religious experience (just look at the title of his famous book: The varieties of religious experience.

I now briefly relate such insights to the topic under consideration: If we understand ancient Judaism and early Christianity as religions, we unavoidably treat them according to the model of modern Christianity. This model then serves as prototype within the discourse of religion. The result (to close my objections on this aspect of current scholarly debate on the beginnings of Christianity) is that the subject of research into religion necessarily appears as research producing ancient representations of an eternal essence called religion.

\section{3. "RELIGION" AS PART OF THE ANCIENT DISCOURSE OF ETHNICITY}

\subsection{Embedded religion}

"If we are not permitted to speak of 'essences', how shall we define a religion at all?" It was the British church historian, Rowan Williams (1989:5), who 
asked this question in an interesting essay. ${ }^{9}$ I presume one is prompted to pose that question too, in view of my deconstruction of the model of religion as the focus of scientific interest in the beginnings of Christianity. Unlike Williams, however, I have tried to show that a new definition of "religion" will not solve the problem of anachronism. It is the essentialist approach which leaves us with the illusion that a new definition of religion might be able to bridge the historical and cultural trench dividing us from the ancient Mediterranean cultures. Indeed some scientists believe that this new term for religion only needs to move to a higher level of abstraction for it to apply to other contemporary cultures or to ancient societies. Others would solve the problem by recourse to a functionalistic concept of religion.

I would therefore reiterate the fact that modern religious discourse owes its existence to a specific cultural and social formation that must be taken seriously. It cannot simply be applied to ancient phenomena. Thus, the question should be asked in a different way. If what we understand by the term "religion" had not yet become an entity separable from other dimensions of social life experiences within ancient Mediterranean cultures, then how were those phenomena, which we count as "religious," understood and experienced in those cultures? Or, and this is the second question: if, as it seems to me, the religious sphere of discourse that we have learned to employ (but only for the past few centuries at that) was neither employed by Jesus, nor Paul, nor Justin, nor Cicero, nor any other person in antiquity, then what sphere of discourse did they employ? To put it the other way around: To which sphere of discourse did Paul's contemporaries relate Paul's statements regarding the newly formed associations later called "Christian"? I proceed to attempt a short answer to the first question.

Years ago Bruce Malina (1986) already gave a convincing answer to my first question. He pointed out that religion in ancient Mediterranean society was "embedded" ("embedded religion"). What is called "religion" today, in the ancient Mediterranean was embedded in the two central social institutions: polity and family/kinship. Malina correctly argues that here lies the fundamental difference between the ancient Mediterranean world and ours, which experiences religion as "disembedded", as a separate and separable sphere of culture or a separate entity (Malina 1986:92-101).

In other words, ancient Mediterranean societies did not perceive "religion" as an individual experience or a social institution standing on its own. Needless to say, other scholars share this opinion as well, among them the well known British scholar, Paul Cartledge (2002). I allow myself to mention that my twin brother, Ekkehard, and I have also taken up Malina's

\footnotetext{
${ }^{9}$ Rowan Williams ([1989] 2002). Does it make sense to speak of pre-Nicene orthodoxy?, in Williams, R (ed), The making of orthodoxy: Essays in honour of Henry Chadwick. Cambrdige, UK: Cambridge University Press.
} 
idea and related it to Early Christianity in our book on the social history of early Christianity (Stegemann \& Stegemann 1999:285ff). The hypothesis finds easy support in the language of the New Testament, which gives obvious hints about the embeddedness of religion in polity and kinship in ancient Mediterranean societies. It is sufficient to recall terms like ekklesia (the term means the gathering of the citizens of a Greek city and was applied to the gatherings of the early Christians; it is misleading to translate this word into "church") or naos theou ("God's temple") or logike latreia (rational service of God, offerings without animals). All such expressions point to the "political" aspect of "embedded religion". On the other hand, numerous expressions are encountered which show that, for example, the Pauline communities understood both their discursive and non-discursive practices within the context of the social institution which we call the family (inter alia oikos, adelphoi).

To sum up, whereas in the modern discourse on religion, discursive as well as non-discursive religious practices are seen as "disembedded", as separate and free-standing entities, the peoples of the ancient Mediterranean experienced comparable phenomena as embedded in polity and family or kinship.

\section{2 "Religion" as part of the ancient discourse of ethnicity}

I now attempt to answer the second question. If Paul and his contemporaries did not share our spheres of religious discourse, then in what sphere was their religious discourse situated? I have postulated the following thesis: The sphere of discourse shared by Paul and his contemporaries was ethnicity. Theirs was an ethnic discourse, a discourse about affiliation to a certain people and all that such affiliation entails. Again, I quote Rowan Williams, with whom I readily agree this time:

The "religion" of classical Greece or Rome ... is simply the totality of cultic practices, mythology and speculation about the gods current among the people of a specific area or ethnic-linguistic unit or network of such units. Religious definition is inseparable from definition as a people or a city or whatever; the de facto context in which a person lives is assumed to be the source for "meaning" the provider of a comprehensive pattern or map of the cosmos.

The aforementioned Paul Cartledge supports this view. He understands religion as part of the ancient Mediterranean ethnic self-definition, demonstrating his standpoint by quoting Herodotus' famous definition of the ethnic identity of the Greek people (Hellenicity), which runs as follows: 
There are many important reasons that would prevent us from doing this even if we wanted to. First and foremost there are the statues and the temples of gods which have been sacked and destroyed; it is necessary for us to avenge these with all our might rather than come to an agreement with the man who did it. Then again there is a matter of Hellenicity (Hellenikon) - that is, our common blood (homaimon), common tongue (homoglosson), common cult places and sacrifices (theon idrymata ... koina kai thysiai) and similar customs (ethea ... homotropa); it would not be right for the Athenians to betray all this.

(Herodotus, History 8.144.2). ${ }^{10}$

According to this statement, the specific worship of a people, which comes closest to what we call a "religion", is part and parcel of ethnicity, along with a common origin, a common language and (special) rules for a common way of life. One could add a common geographical background. Interestingly, it is what the members of one ethnos have in common that simultaneously distinguishes them from the members of another people. To generalise, in other words, what is called "religion" in our world was an aspect of ethnicity in the world of Paul, Cicero and Jesus.

There can be no doubt as to the anachronism of the term ethnicity itself (which was coined in the last century). However, as Jonathan M Hall (2002:16) states, the Greeks (and other ancient peoples)

... could, however, talk "around" these concepts. When they discuss how particular populations are characterized by their diaita (daily way of life), ethea (dispositional habits) and nomoi (regulated norms), or speculate that mental values and physical comportment may be inculcated in the young through paideia (education), it is difficult to maintain that they are not talking about culture in certain senses that we are able to recognize.

Therefore a definition of ethnicity can only pave the way for an orientation into the sphere of discourse we enter by speaking about ethnicity. Again, Hall (2002:9-10) provides us with a very helpful formulation of what can be called an ethnic group:

(i) The ethnic group is a self-ascribing and self-nominating social collectivity that constitutes itself in opposition to other groups of a similar order. (ii) Biological features, language, religion or cultural traits may appear to be highly visible markers of identification but

${ }^{10}$ The translation follows Jonathan M Hall (2002:189). 
they do not ultimately define the ethnic group. They are, instead, secondary indicia (...) or "surface pointers". (iii) Ultimately, the definitional criteria or "core elements" which determine membership in an ethnic group - and distinguish the ethnic group from other social collectivities - are a putative subscription to a myth of common descent and kinship, an association with the specific territory and a sense of shared history. (iv) The ethnic group is neither static nor monolithic and is often subject to processes of assimilation with, or differentiation from other groups. (v) Since individuals possess a broad repertoire of social identities and roles that they adopt in varying circumstances and for specific goals and purposes, membership in an ethnic group will not always be the salient dimension of identification, though it tends to assume greater importance at times when the integrity of the ethnic group is threatened. (vi) Finally, ethnicity often emerges in the context of migrations, conquest or the appropriation of resources by one group at the expense of another.

Shaye J D Cohen (1999), who wrote an insightful book entitled The beginnings of Jewishness, comes to similar conclusions with reference to the Jewish people of old. His explanations are extremely important, since he takes into consideration the relevant contemporary discourse on ethnicity like Jonathan Hall - and then specifies the meaning system, which enables a better understanding of the affiliation to a certain people. He achieves what I would like to call with the words of C Geertz a "thick description" of the ancient discourse on Judaism in terms of a discourse about ethnicity:

The Jews (Judaeans) of antiquity constituted an ethnos, an ethnic group. They were a named group, attached to a specific territory, whose members shared a sense of common origins, claimed a common and distinctive history and destiny, possessed one or more distinctive characteristics, and felt a sense of collective uniqueness and solidarity. The sum total of these distinctive characteristics was designated by the Greek word loudaismos. As we shall see, the most distinctive of the distinctive characteristics of the Jews was the manner in which they worshiped their God, what we today would call their religion. But loudaismos, the ancestor of our English word Judaism, means more than just religion. For ancient Greeks and contemporary social scientists, 'religion' is only one of many items that make a culture or a group distinctive. Perhaps, then, we should translate Ioudaismos not Judaism' but "Jewishness". 
I now briefly relate these insights to the situation of early Christian groups.

The members of Christian groups (Christianoi) in antiquity constituted an ethnos. They were described as a group with members affiliated to a heavenly person, Jesus Christ, whom they understood as the son of God and founder of their community. The sacrificial death of their founding hero communicated to them a sense of common origins. As a dedicated people of $\mathrm{God}(\mathrm{Rm} 1: 7)$ and an elect community, they claimed a common and distinctive history and destiny, which - in their view - would find its happy ending for believers in the resurrection from the dead and a transformation of their bodies for eternal living. The Christianoi possessed many distinctive characteristics (I mention only Gl 3:28), and felt a sense of collective uniqueness (as God's - new people, elected from among many peoples, a community of holy human beings) and solidarity (love commandment, love of enemies etc). The sum total of these distinctive characteristics was designated by the Greek word Christianismos, which first appeared at the beginning of the second century (Letters of Ignatius). Perhaps the contemporaries of the first Christianoi experienced as the most distinctive of their distinctive characteristics the manner in which they worshiped their God and his son Jesus Christ. Like the Judeans outside Judea, the Christianoi did not worship their God in a some temple cult, and like the Judeans they were not able to integrate their God into the pantheon of the gods of other peoples. So, Christianismos meant more than cult or "religion." Like Judaismos, it was a way of life.

Unlike the many other ancient peoples, the Christianoi as God's people shared no common genealogical descent from a common ancestor. Instead, they were connected through fictive kinship, which means that they belonged to the household of God (familia dei) and ultimately traced their birth to and from God (baptism as symbolic (re-)birth). The believers (hoi pisteuontes), as they called themselves in the time of Paul the apostle, understood themselves as a people of God, next to the Israelites and the Gentiles, thus as tertium genus, as they were to call themselves some decades later.

\subsection{Ethnicity as a cultural term}

To understand early Christianity in terms of ethnicity presupposes a model of ethnicity without the characteristics of specific territory or common blood. A similar model had emerged within Hellenistic culture quite a long time before the first century (Cohen 1999:109ff). Whereas for Herodotus common blood and language, a common cult and way of life served as identity markers of an ethnos, a distinctive people, this point of view changed later on during the period of Hellenism. As Cohen (1999:132) says: "Thus 'Hellene' changed from an ethnic or ethno-geographic term to a cultural term." Whether someone was 
a Greek or not depended on his social behaviour, his language (Greek), his way of life and his cultic practices. It was not simply a matter of birth or physis (Paul speaks of himself and Peter as physei loudaioi (GI 2:15). The same is true for ancient Israel. Cohen has demonstrated that since the time of the Hasmoneans Judaismos (the practice of Judean customs) became a cultural term. I quote Cohen's (1999:137) view:

\begin{abstract}
Greekness once had been a function of language and culture. Similarly, Jewishness (Judaeanness) once had been a function of birth and geography but now in the Hasmonean period it became a function of religion and culture. Anyone could become a Hellene or a loudaios through a change in values and culture. However, whereas Greekness was completely shorn of its ethnic and geographic connections, Jewishness was not. For most loudaioi in antiquity, the ethnic definition was supplemented, not replaced, by the religious definition. Jewishness became an ethno-religious identity.
\end{abstract}

Perhaps it would be better to speak of ethno-cultural identity, since Cohen himself knows that religion is a modern notion. Whatever the case, it is of fundamental importance that long before the emergence of Christian groups, Hellenistic discourse on ethnicity allowed for the affiliation of people to various ethnic groups, whether Greek or Judean, without an exclusive attachment to common blood and geography. Furthermore, the cultic and cultural aspects of ethnicity in discourse about ethnicity included a person's way of life and way of worship, which in turn served as the identity and boundary markers of Hellenismos and loudaismos. Those who worshiped the God of Israel and lived the Judean way of life (respecting the customs that comprised Judaism, and especially living according the commandments of the Torah), could be identified as Judeans (Ioudaios). Today it is customary to for most people to understand the word "Jew" as referring to a person belonging to a certain religion. Yet in the first century, a Judean meant a person who belonged to a certain people, an ethnic group defined in terms of special customs and a special cult.

\title{
4. CONCLUSION
}

I understand the beginnings of Christianity (I prefer to speak of the beginnings of Christianismos, in German: Christsein = being a Christian, like Judaismos, Judaism, the customs and behaviours of Judeans) - as the emergence of a new people. The members of this ethnos (or, in Latin, genus) saw their origins in the sacrificial death of Christ, the son of $\operatorname{God}(\mathrm{Rm} 6)$. They understood 
themselves as a chosen people, chosen by the God of Israel as a new laos ex ethnon (Ac 15:13), a new people out of the peoples (Gentiles), who simultaneously transcended the boundaries of all peoples ("here is neither Jew nor Greek", GI 3:28). Later on - certainly in the 17-18th century, perhaps even earlier - one of the distinctive characteristics of the Christianoi, their worship of the one God and his Son Jesus Christ, lost its connection with the ethnic discourse (was "disembedded") and became a basic feature of what we today call "religion". At the contemporary end of this process stands the experience of religion as a private matter. Religion was first disembedded from polity and - a very recent phenomenon - was disembedded from kinship and family. Individualism now sets the boundaries of the contemporary EuroAmerican sphere of discourse on most topics, and notably on discourse on religion.

\section{Works consulted}

Bhabha, H K 1994. The location of culture. London: Routledge.

Bousset, W 1903. Das Wesen der Religion, dargestellt an ihrer Geschichte. Halle. Boyarin, D 1999. Dying for God: Martyrdom and the making of Christianity and Judaism. Stanford, CA: Stanford University Press.

Buell, D K 2001. Rethinking the relevance of race for rarely Christian self-definition. HThR 94, 449-476.

Burkert, W 1998. Kulte des Altertums: Biologische Grundlagen der Religion. München: C H Beck.

Cartledge, P 2002. The Greeks: A portrait of self and others. Cary, NC: Oxford University Press.

Castelli, E A 1998. Gender, theory, and the rise of Christianity: A response to Rodney Stark. Journal of Early Christian Studies 6, 227-257.

Cohen, S J D 1999. The beginnings of Jewishness: Boundaries, varieties, uncertainties. Berkeley, CA: University of California Press.

Collins, R F 1993. The birth of the New Testament: The origin and development of the first Christian generation. Collegeville, MN: Liturgical Press.

Crossan, J D 1999. The birth of Christianity: Discovering what happened immediately after the execution of Jesus. San Francisco, CA: HarperSanFrancisco.

Destro, A 2000. Come nasce una religione: Antropologia ed esegesi del Vangelo di Giovanni. Bari-Roma: GLF editori Laterza.

Frend, W C 1984. The rise of Christianity. London: Darton, Longmann \& Todd.

Hall, J M 2002. Hellenicity: Between ethnicity and culture, Chicago, IL: The University of Chicago Press.

James, W [1902] [1985] 2003, The varieties of religious experience, in Olson, C (ed), Theory and method in the study of religion: A selection of critical readings, 378-390. Belmont, CA: Wadsworth/Thomson Learning. (Published in 1985 by Harvard University Press, Cambridge, Mass.)

Jossa, G 1997. Il cristianesimo antico: Dalle origini al concilio di Nicea. Roma: NIS. King, R 1999. Orientalism and religion: Postcolonial theory, India and the "Mystic East". London: Routledge. 
Lüdemann, G 2000. Das Urchristentum, I u. II. Theologische Rundschau 65.

Mack, B L 1995. Who wrote the New Testament. San Francisco, CA:

HarperSanFancisco.

Malina, B J 1986. Religion in the world of Paul. Biblical Theology Bulletin 16, 92-101.

Matthes, J 1993. Was ist anders an anderen Religionen?, in Bergmann, J, Hahn, A \& Luckmann, T (Hrsg), Religion und Kultur: Sonderheft der Kölner Zeitschrift für Soziologie und Sozialpsychologie, Opladen 16-30.

Mimouni, S C 1998. Le Judéo-christianisme ancien: Essais historiques. Paris: Cerf.

Moo, D 1996. The epistle to the Romans. Grand Rapids, MI: Eerdmans.

Nodet, E \&Taylor, J [1998] 2002. Essai sur les origines du Christianisme. Paris: Editions du Cerf.

Otto, R 1926. Das Heilige über das Irrationale in der Idee des Göttlichen und sein Verhältnis zum Rationalen. Gotha: Leopold Klotz.

Reinstorf, D 2002. Metaphorical stories in Luke's narrative world: A challenge to a conventional worldview. DD dissertation, University of Pretoria.

Sabbatucci, D 1998. Kultur und Religion. HRWG 1, 43-58:57f.

Sachot, M 1998. L'invention du Christ: Genèse d'une religion. Paris: O Jacob.

Segal, A F 1986. Rebbecca's children: Judaism and Christianity in the Roman world. Cambridge, MA: Harward University Press.

Simonetti,M 1994. Ortodossia ed Eresia tra I e I/ secolo. Soneria.

Smith, W C 1991. The meaning and end of religion. Minneapolis, MN: Fortress.

Stark, R 1996. The rise of Christianity: A sociologist reconsiders history. Princeton, $\mathrm{NJ}$ : Princeton University Press.

Stegemann, W 2001. Christentum als universalisiertes Judentum? Anfragen an Theissens "Theorie des Urchristentums". Kirche und Israel 16,130-148.

Stegemann, E W \& Stegemann, W 1999. The Jesus movement: A social history of the first century. Minneapolis, MN: Fortress.

Theissen, G 1999. The religion of the earliest churches: Creating a symbolic world. Minneapolis, MN: Augsburg Fortress.

Theissen, G 2000. Die Religion der ersten Christen: Eine Theorie des Urchristentums. Gütersloh: Kaiser.

Trevijano,R 1994. Orígenes del Cristianismo: El trasfondo judío del cristianismo primitivo. Salamanca.

Von Harnack, A 1924. Die Mission und Ausbreitung des Christentums in den ersten drei Jahrhunderten, 1. Bd: Die Mission in Wort und Tat. Leipzig.

White, $\mathrm{H}$ 1985. Tropics of discourse: Essays in cultural criticis. Baltimore, MD: The John Hopkins University Press.

Williams, R [1989] 2002. Does it make dense to speak of pre-Nicene orthodoxy?, in Williams, R (ed), The making of Orthodoxy: Essays in honour of Henry Chadwick. Cambridge, UK: Cambridge University Press. 